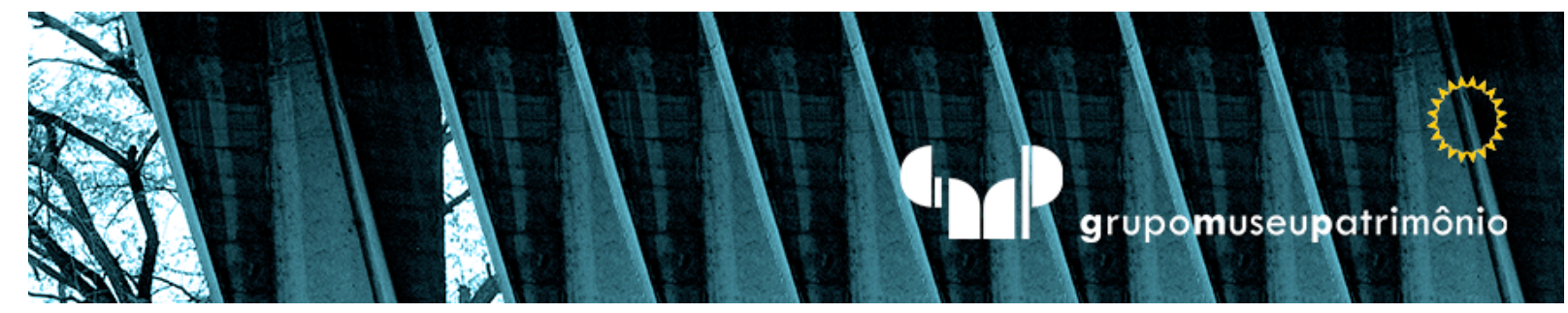

\title{
Contrapposto: a antítese como construção de significado
}

Contrapposto: la antítesis como construcción de significado

Contrapposto: antithesis as construction of meaning

Betty Mirocznik

Faculdade de Arquitetura e Urbanismo da Universidade de São Paulo, São Paulo, Brasil.Betty.arq.18@gmail.com 


\section{Resumo}

Problematiza-se aqui, a profusão das imagens que circulam pelas mídias na sociedade do hiperreal. Essas imagens planas captadas nas telas de TV, computador e celulares, simulam a realidade, sendo denominadas por Baudrillard, como simulacro. Nesse contexto, é imperativo produzir-se uma imagem de resistência, que desperte o mistério e a experiência em cada um imagem-enigma. Para essa discussão, elegeu-se a obra Contrapposto de Bruce Nauman.

Palavras-Chave: Sociedade do hiperreal. Simulacro. Jean Baudrillard. Imagemenigma. Bruce Nauman.

\section{Resumen}

Aquí se problematiza, la profusión de imágenes que circulan por los medios en la sociedad hiperreal. Estas imágenes planas capturadas en pantallas de TV, computadora y celulares simulan la realidad, llamada Baudrillard, como simulacro. En este contexto, es imperativo producir una imagen de resistencia, que despierte el misterio y la experiencia en cada uno - imagen enigmática. Para esta discusión, se eligió el trabajo Contrapposto de Bruce Nauman.

Palavras-Clave: Sociedad Hiperreal. Simulacro. Jean Baudrillard. Imagenenigmática. Bruce Nauman.

\section{Abstract}

It is problematized here, the profusion of images that circulate through the media in the hyperreal society. These flat images captured on TV, computer and cell phone screens, simulate reality, being called by Baudrillard, as simulacrum. In this context, it is imperative to produce an image of resistance, which awakens the mystery and the experience in each one - enigma image. For this discussion, the work Contrapposto by Bruce Nauman was chosen.

Keywords: Hyperreal Society. Simulacrum. Jean Baudrillard. Enigma Image. Bruce Nauman. 


\section{INTRODUÇÃO}

Iivemos em uma civilização da imagem, refém do nosso olhar incessantemente exposto e submisso a uma multiplicidade de signos como os que circulam pelas mídias digitais, em uma sociedade hiperreal com imagens hegemônicas e planas que transitam nas telas dos computadores, celulares ou televisão. Nessa sociedade da simulação a imagem assume o papel de simulacro, denominação dada pelo filosofo francês Jean Baudrillard. Aludindo a esse conceito, Ricardo Fabbrini elucida em seu artigo Imagem e Enigma que,

[...] o simulacro para Baudrillard é a imagem na qual nada é encoberto pelo simples motivo de que nela não haveria coisa alguma a ser ocultada. [...] Os simulacros são, assim, imagens de um mundo sem falhas, ou de uma continuidade sem fissuras, são imagens planas (ainda que HD ou 3D); chapadas; lisas; superficiais, epidérmicas; peculiares; sem recuo; sem relevo; sem perspectiva, sem enigma, sem mistério; sem face oculta; sem outro lado; sem pregas; sem dobras; sem cimo; sem avesso; sem linha de fuga, nos termos salpicado pelo autor em diversos ensaios. Essas imagens seriam desérticas, vazias porque, 
entre outros motivos a inflação ou excesso de signos teria produzido, em aparente paradoxo, uma deflação de sentido. (2016, p. 245)

Nesse contexto, os simulacros motivariam uma atração pela imagem reduzida à materialidade do significante, definida por Baudrillard como uma paixão niilista dos modos de desaparição do real, ou seja, um modelo de um real sem origem na realidade. Sendo assim, as imagens apreendidas como hiperreais mais reais que o real - embora percebidas sensorialmente, mostram-se aprisionadas a uma exiguidade ontológica quando comparadas à percepção experimentada do mundo real, cada vez mais inacessível.

O fascínio pelas imagens técncias é assim inseparável, segundo Baudrillard, do verdadeiro trabalho de luto em curso, não apenas pela morte do real, mas também pela morte de certa ideia de cultura, vinculada ao erotismo e à sedução, ao sagardo e ao segredo. Estaríamos presenciando na cultura do simulacro, em outros termos, a morte lenta, comatosa, que se protrai no tempo, de um referencial perdido; ou seja: um luto prolongado, sem redentor suspiro, pela desapariação do real, e, por conseguinte, de um campo de sentido a ele associado. (FABBRINI, 2016, p. 246)

Nesse viés, há de se examinar em que medida na sociedade da hipervisibilidade, do tráfego ilimitado de signos, ser possível ainda se produzir uma imagem que traga algum enigma, que suscite certo mistério ou recuo. A procura por uma imagem-enigma como imagem de resistência indicia o esforço de vários artistas, dentre eles Bruce Nauman, em recuperar não só a potência da visão, mas também, a experiência multissensorial como um todo. Das obras artísticas decorreria uma vivência de suspensão entre o tempo presente e aquele que se anuncia, dito de outra forma, um desejo inquieto em permanente expectativa com a pergunta recorrente: algo ocorrerá? Há expectação de que alguma coisa surja desse impulso que força a imagemenigma para fora de si mesma, para o informe, como índice de alternativa ao dito real. Realiza-se, portanto, uma busca por uma imagem que se oponha à nossa era irreferencial, da desrealização do real (FABBRINI, 2016). 
Retomando Baudrillard, esse enigma da imagem tem por função devolver ao olhar a construção da imagem e sua intrínseca relação com o desejo, fantasia e fascinação de cada um. O filósofo a isso denomina como qualidade pensativa da imagem, como qualidade de algo que nos pensa, ou ainda, como qualidade de um pensamento sem reflexão (FABBRINI, 2016).

Pode-se perguntar, nesta direção, como esperar que uma imagem force o pensamento, que rompa com o provável, com as convenções e com o convencionalismo para dar lugar à percepção. As imagens-enigmas em meio à prática dos simulacros que trafegam ininterruptamente pelas mídias atuais, atuaria como resistência à submissão da cultura de massa. A busca por uma imagem capaz de nos desorganizar, de produzir empatia em oposição as imagens que reforçam o imaginário do bom gosto e seus fortes referenciais - a difícil realidade ou em sentido contrário, a realidade a ela atribuída-, uma imagem desestabilizadora que instaura uma tensão entre o objeto representado e o real. É nesse espectro da indiscernibilidade que o imponderável ocorre resultando na distância, mistério e enigma dessas imagens, criando-se assim, a verdadeira experiência estética. Essa prática atuaria diretamente na percepção e autoconsciência por parte do público de sua familiaridade com as estruturas tecnológicas cada vez mais corrente.

\section{BRUCE NAUMAN}

Bruce Nauman, nasceu nos Estados Unidos em 1941. Criado em um subúrbio de Milwaukee, optou por estudar matemática, filosofia e teoria musical antes de ingressar no curso de artes visuais da Universidade de Wisconsin-Madison, formando-se em 1964. Após finalizar o curso, se mudou para São Francisco matriculando-se no programa de mestrado da Universidade da Califórnia em Davis. O departamento de arte recém aberto aceitava praticamente a todos que tinham interesse em frequentá-lo. Na aplicação para o curso de arte, com foco na pintura, submeteu seu portfólio de trabalhos de graduação: abstrações geométricas pintadas em camadas nos tons médios da paleta. Após um ano de estudos na Davis desistiu definitivamente de pintar. Ao longo do curso teve 
oportunidade de trabalhar várias técnicas, materiais e formas de expressão visual, no entanto, o mais radical e duradouro dos seus empreendimentos na Davis envolveu curta-metragens que documentavam o uso de seu corpo encenando performances ao vivo. Após formar-se, sublocou um estúdio ao norte de São Francisco onde continuou a fazer filmes sobre vários de seus atos físicos cotidianos. A essa altura, para Nauman, a arte se relacionava mais a atividade do fazer do que ao produto final propriamente dito (FRANKEL, 2018).

Há de se considerar aqui os conceitos propostos pelo movimento artístico sul californiano Light and Space (Luz e Espaço) ao longo da década de 1960, que, em muito, impactaram as produções de Nauman. As obras pertencentes a esse movimento investiam no potencial extrasensorial da luz ao utilizar o espaço dentro e ao redor dela como um quadro imersivo que aumentava a consciência do visitante em relação à experiência mente-corpo. Esses trabalhos reduziam a arte a seus elementos mais puros como luz e espaço, eliminando a hierarquia inseparável das imagens narrativas e apresentando ao fruidor uma experiência corporal direta, que operava com estímulos incomuns em uma configuração desconhecida. Em grande medida, esses trabalhos desmaterializados dramatizam o caráter mutável do sensório, pautando-se na construção do espaço pela luz e da materialidade a partir da imaterialidade. A luz, comumente entendida como um conceito vago, adquire uma presença física e passa a ser percebida e conceituada de forma concreta. Essa narrativa foi abordada pelos artistas Robert Irwin, James Turrell, Michael Asher e Maria Nordman no movimento Light and Space. Para Turrell,

Ao trabalhar com a luz, o que é realmente importante para mim é criar uma experiência de pensamento sem palavras, para tornar a qualidade e a sensação de luz em si como algo realmente tátil. A luz tem uma qualidade aparentemente intangível, mas pode ser fisicamente sentida. Muitas vezes as pessoas alcançam e tentam tocála (In: BROWN, 1985, nossa tradução). 


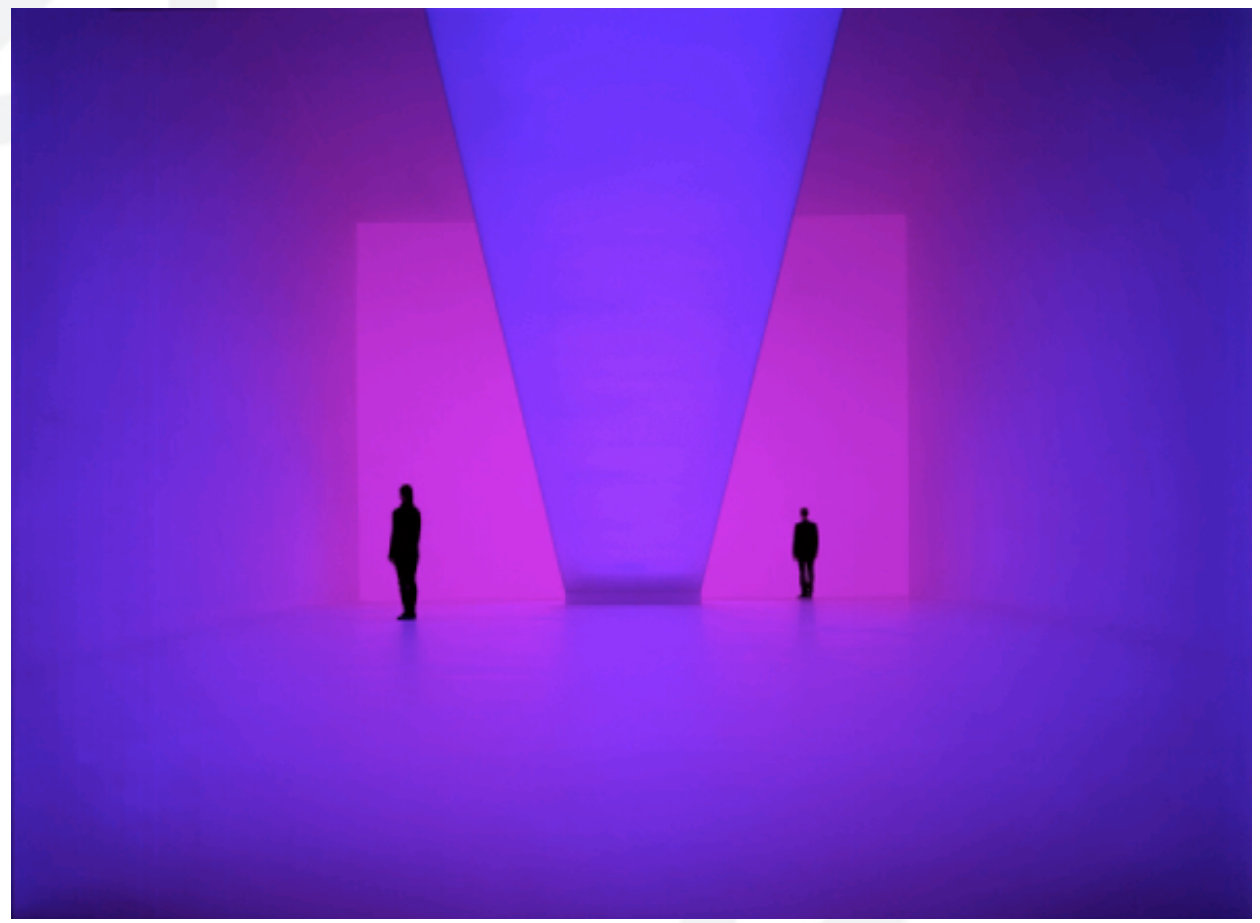

Figura 1: Bridget's Bardot, James Turrell, 2008. Fonte: azurebumblel

Nas produções do movimento Light and Space foram utilizados materiais translúcidos e transparentes recentemente disponíveis como resina de poliéster, fibra de vidro, acrílicos, vidros revestidos e plásticos de todos os tipos, além de luzes neon e fluorescentes. Esses materiais refletiam, refratavam e filtravam a luz, enfatizando as formas como a luz transpassa ou se curva no espaço. Em constraste aos artistas de Los Angeles, a estética minimalista de Nova York abraçou materiais industriais impermeáveis com sombras e reflexões minimizadas em prol da concretude e estabilidade do objeto específico. Embora a Pop Art e o Minimalismo tenham também utilizado alguns dos materiais do movimento Light and Space, a intenção era a de oposição ao efeito ilusionista em detrimento do suporte material.

Desta forma, as obras do movimento Light and Space exemplificavam uma transição na experiência estética do belo em direção ao sublime, instigando o fruidor a acessar sua conexão com a humanidade a partir de experiências compartilhadas de ansiedade e resposta emocional - como imagens-enigma. A 
arte se afastava da ideia de beleza universal e seguia em direção a uma nova experiência estética, um conceito do sublime que pudesse acomodar as tensões da modernidade.

Esses artistas criaram instalações minimalistas aparentemente infinitas, cuja presença da luz ora era abstrata, ora concretamente real. Dentro desses espaços os fruidores perdiam o equilíbrio ao serem envolvidos por uma percepção esmagadora que gerava uma experiência estética tensa entre a realidade e a irrealidade, a materialidade e a imaterialidade, o visível e o invisível. Outra reflexão possível para esse conflito é considerar como real a experiência individual de cada um face às formas de representação cultural que o codificam.

Nesse período, Nauman explorou em uma série de trabalhos, a forma em que a percepção é moldada pelo uso da luz que banha o ambiente. Esses trabalhos imersivos estavam em sintonia com o movimento californiano. No entanto, suas instalações diferiam dos ambientes de James Turrell e Robert Irving, pois, se utilizavam de espaços apertados e incômodos, projetados propositalmente, para criar um desconforto no observador. Utilizando novas mídias, encenava expressamente para a câmera ações artísiticas que produziam um tipo inexpressivo e factual de imagens, narrativa estimulada pelas ideias de Man Ray, Merce Cunningham e John Cage, além, de composições baseados em teorias da linguagem com o intuito de transformar uma atividade normal em uma apresentação formal, no mesmo viés que Cunningham fazia com a dança e Cage com a música.

Nauman concentrou-se na maneira como as operações do acaso e a tensão entre profissionalismo e amadorismo presentes nas obras de Cage e Cunningham mudavam a função do que é arte e o que o artista faz. Suas leituras do livro Ludwig Wittgenstein's Philosophical Investigations (Investigações Filosóficas de Ludwig Wittgenstein) publicado postumamente em 1953, inspiraram seu pensamento na criação de trocadilhos visuais e jogos de palavras que exploravam a linguagem, não como uma ferramenta de 
comunicação, mas, como um modo de investigação através de argumentos contraditórios e implausíveis. Essa prática o levou a Man Ray que no início dos anos 1920 desafiou a alegação de fotografia como verdade ao exaltar a capacidade da câmera em traduzir de forma lúdica objetos improvisados e facilmente descartáveis, transformando-os em uma nova forma de escultura. A partir dessas reflexões, ao invés de produzir objetos estáticos se concentrou nas investigações lingüísticas orientadas a processos que significava, trabalhar com o que estivesse disponível. Sua concepção revisionista da prática escultural tornou-se metodologicamente contingente nas lentes fotográficas. A câmera assumiu um papel ativo, testando idéias filosóficas e transformando o corpo do artista em forma escultural (FRANKEL, 2018).

Várias foram as obras em que Nauman explorou esse recurso. Trataremos aqui da série intitulada Contrapposto, exibida em sua restrospectiva Disappearing Acts (Atos que desaparecem) que teve lugar no MOMA e PS1 em Nova York no ano de 2019. Nestas instalações pode-se identificar imagens-enigmas que operam como resistência por forçarem outros modos de percepção e apreensão da obra de arte, transformando-a em objeto estético. Esses trabalhos despertam uma nova fruição no sujeito, mais lenta e hesitosa, suscitando outra forma de experiência estética e multissensorial. Frente à saturação de imagens a que somos expostos, redireciona o observador do automatismo e hedonismo para uma percepção pensativa e sensível.

\section{CONTRAPPOSTO}

Verdades são ilusões sobre as quais cada um esquece o que de fato são; metáforas desgastadas e sem poder sensual; moedas que perderam suas fotos e que agora valem somente pelo seu metal, não mais como moedas. NIETZCHE

Na década de 1960, processou-se uma mudança estética radical que alterou tanto a definição de arte quanto as maneiras pelas quais os objetos de arte eram experimentados. Essa mudança está relacionada ao papel da fotografia e do vídeo na retomada de novas práticas artísticas - happenings, ativismo, arte 
conceitual, land art, entre outras. Esses novos procedimentos acionavam um campo expandido de operações que envolvia várias formas de reprodução, replicação e repetição. Nesse período, houve também uma mudança crítica na relação da fotografia e vídeo com a escultura, escrita e performance, pois, artistas que não se consideravam fotógrafos no sentido clássico do termo, começaram a usar a câmera para seus projetos que não eram especificamente fotográficos. Nesse interim, fica disponível ao público a primeira geração de câmeras de vídeo com preços mais acessíveis e de fácil manuseio, que possibilita que um maior número de artistas faça uso dessa nova tecnologia em seus projetos e reflexões. Essas câmeras permitiam que se fizessem gravações sem qualquer assistência, dando aos artistas maior autonomia. Rapidamente, Nauman aderiu a essa narrativa ao filmar suas performances seu deslocamento pelos limites do estúdio que ocupava. A maioria dessas fitas, de certa forma instigadoras, tinha a duração de uma hora, tempo prolongado que permitia a repetição misturada à sensação de tédio (FRANKEL, 2018).

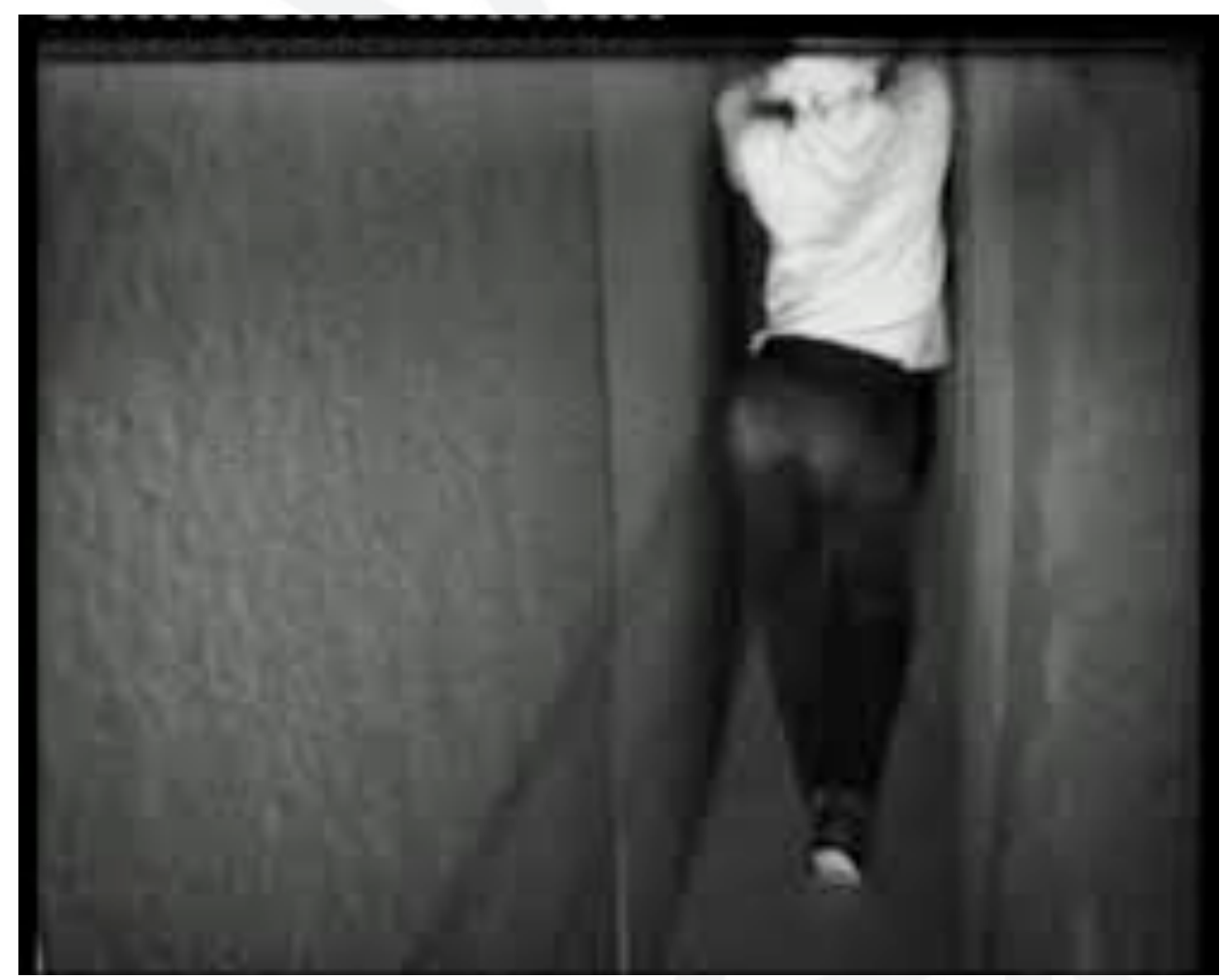

Figura 2: Walk with Contrapposto, Bruce Nauman, 1968. Fonte: encrypted 
Uma das obras mais emblemáticas desse período foi a instalação Walk with Contrapposto de 1968, na qual filma em perspectiva, a partir de uma câmera fixada no final de um corredor estreitamente construído, seu movimento pelo espaço. O corpo do artista, seus modos e gestos figurativos a cada passo lento - nas idas e vindas pelo corredor -, com o dorço fora dos eixos dos quadris e as mãos entrelaçadas atrás da cabeça, definem o espaço. Nesse vídeo seminal, Nauman se concentra nas restrições do espaço dando ênfase ao aprisionamento do ambiente opressivo. Esse é um trabalho de performance sobre quase nada, um espetáculo do eu solitário, uma obra que medeia o corpo à vontade rigorosa de seus impulsos de movimento e do espaço inseparável - paredes e chão. Impõe diferentes graus de tensão: da ambivalência real - física e emocional - à recepção estética do público e críticos. Um ponto de vista isolado que absorve a todos.

Nauman é conhecido por usar trabalhos anteriores como repertório para novas obras. Um trabalho antigo pode, frequentemente, servir como ponto de partida para um novo projeto que proporá outros pontos de vista e reflexão. $O$ corredor da Walk with Contrapposto, pensado originalmente como um suporte, se perpetuou em várias obras da década seguinte. Nauman tomou partido desse recurso para criar espaços que tinham por função tensionar o observador ao deixá-lo desconfortável. No entanto, um dos benefícios de uma longa carreira, é a chance de reavaliar e ajustar conceitos com novos modos de pensar. Nesse sentido, é a partir da Walk with Contrapposto que Nauman se inspira para fazer seu remake mais fiel - uma espécie de reencarnação de uma performance após um hiato de 47 anos - a série de instalações intituladas Contrapposto que se debruça, primordialmente, sobre a condição do corpo, mas, agora, sem o corredor. 


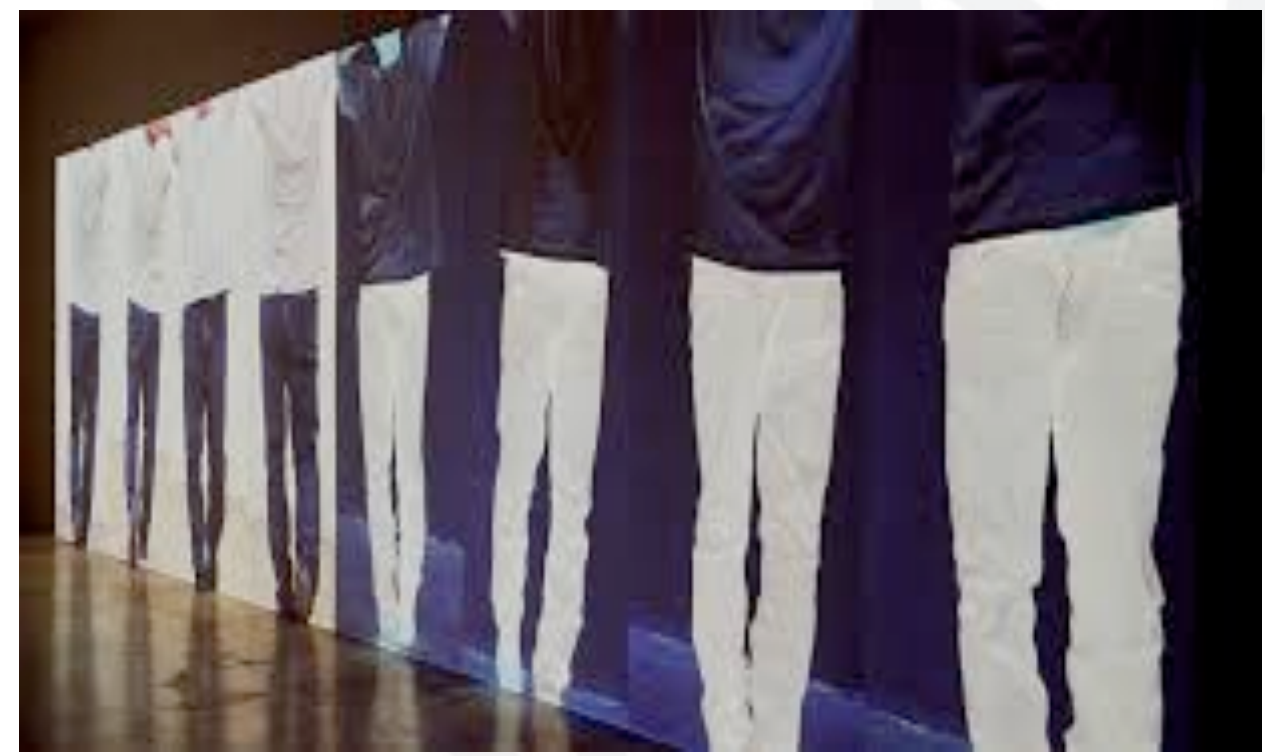

Figura 3: Contrapposto Studies i e ii, Bruce Nauman, 2015-16. Fonte: autoral

Em 2015-16, Nauman revisita a ideia que havia explorado na Walk with Contrapposto. Em seu novo trabalho exposto no MOMA, Contrapposto Studies, I through vii, o artista vestido de camiseta e jeans, mais uma vez, percorre a extensão de seu estúdio, mas, diferentemente da primeira versão na qual utilizou uma câmera portátil modelo Portapak, filma em HD. O uso dessa tecnologia resulta num trabalho complexo e monumental com imagens e som de última geração e pós produção digital. Nesse trabalho, Nauman manipula as imagens de várias maneiras: inteiras, fragmentadas, alternadas entre positivo e negativo. As projeções são acompanhadas por uma trilha sonora que registra não apenas os sons gerados pela atividade de Nauman, mas, também, pelos ruídos provenientes dos equipamentos utilizados para a gravação. 


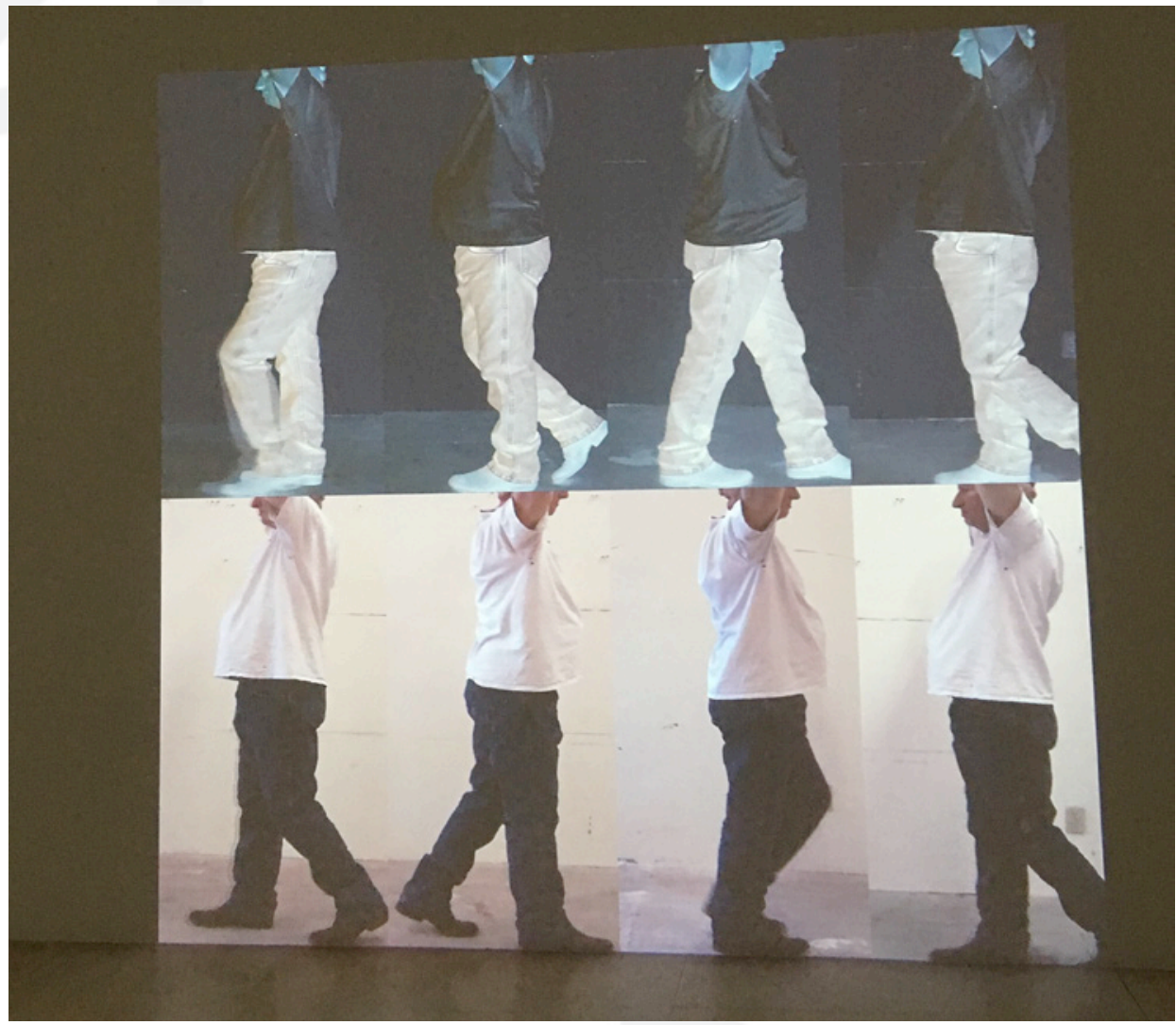

Figura 4: Contrapposto Studies iii, Bruce Nauman, 2015-16. Fonte: autoral

Contrapposto Studies, i through vii teve sete grandes projeções que ocuparam várias salas do MOMA. Na primeira galeria foi exibido um vídeo Contrapposto Studies $i$, que reproduzia a caminhada de Nauman em nossa direção, seu giro e caminhada em direção oposta. O movimento repetitivo fez com que a filmagem parecesse interminável. Seus passos irregulares realçavam uma perna e depois a outra, no entanto, por conta do passar dos anos, seu caminhar já não se equiparava ao do trabalho de origem Walk with Contrapposto. As projeções subsequentes mostravam um trabalho que pode ser definido como formal - obtido a partir de inversões nas imagens de Nauman caminhando de um lado para o outro, de frente e de perfil. Essas imagens foram renderizadas em negativo transformando o jeans escuro em cor de baunilha, a camiseta branca em azul, além, do tom de sua pele. A reversão da filmagem em alguns dos vídeos fez com que se tivesse a impressão 
de que ele andava para trás, que nunca ocorreu. Esses binários transmitiam um tipo de lógica serial. Vem daí o título Contrapposto, que tem sua matriz nas antigas teorias da antítese da retórica, na qual, cada elemento encontra seu oposto e é a partir desse conflito que o significado é produzido.

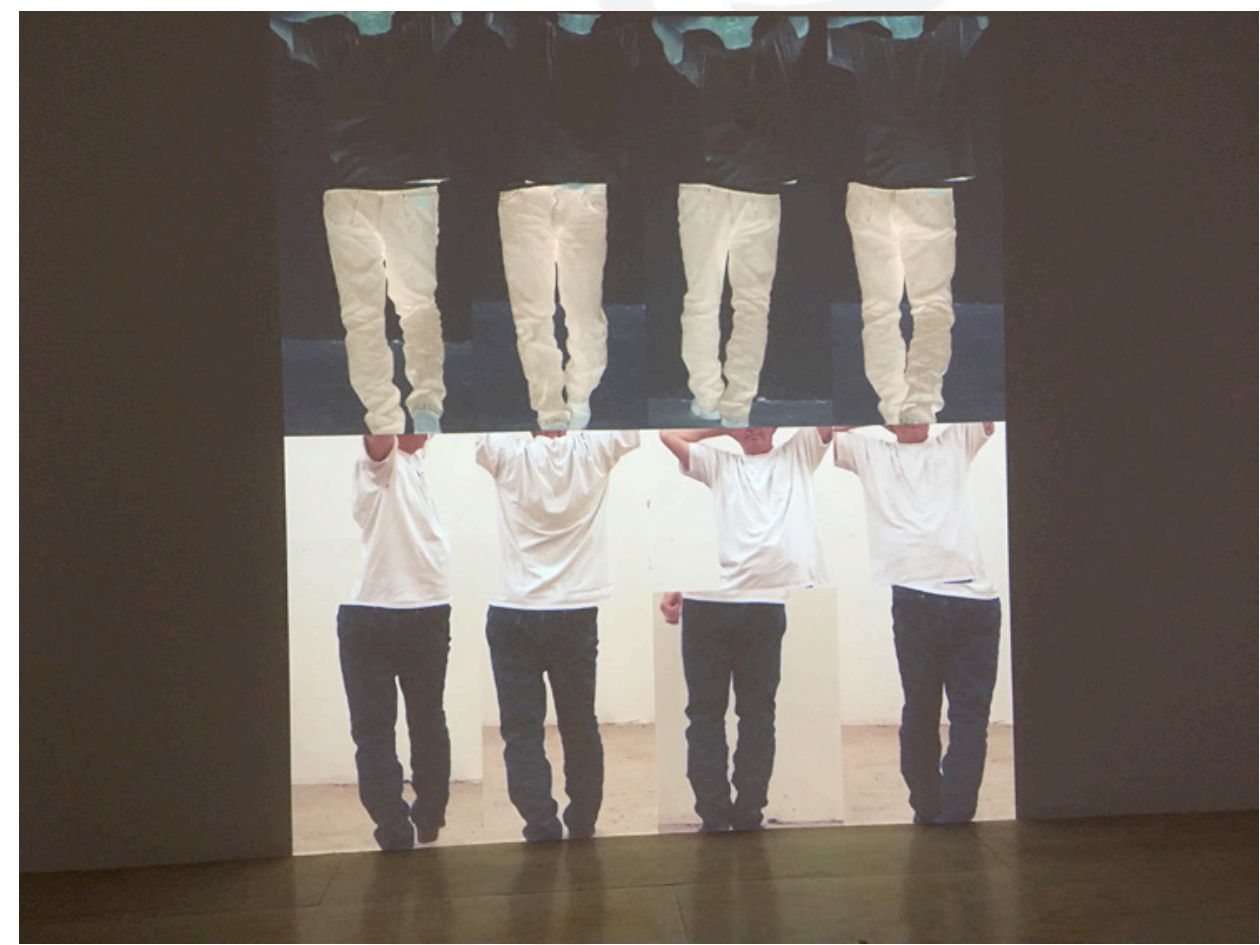

Figura 5: Contrapposto Studies iv, Bruce Nauman, 2015-16. Fonte: autoral

Em outra galeria foi projetado o vídeo Study iv que apresentava corte horizontal na figura de Nauman, dividindo-o em duas partes. Nele, Nauman continua caminhando, mas, com sua imagem seccionada em dois quadros que retratam movimentos desintonizados entre si - a parte superior de seu corpo vai para a frente enquanto suas pernas ficam alguns passos atrás. $O$ efeito da tela dividida, incialmente lúdico, passa a ser desconcertante quando os pés ficam voltados para o lado oposto da cabeça e do tronco. Essas divisões atingem altura vertiginosa nos vídeos Studies vi e vii, nas quais Nauman é projetado em duas linhas horizontais que são subdivididas por mais sete linhas, resultando em catorze quadros. A fragmentação da imagem somada ao 
desalinhamento dos movimentos causa estranheza no observador. Por vezes, quadros inteiros ficam sem nenhuma projeção, deixando exposta a parede branca do museu.

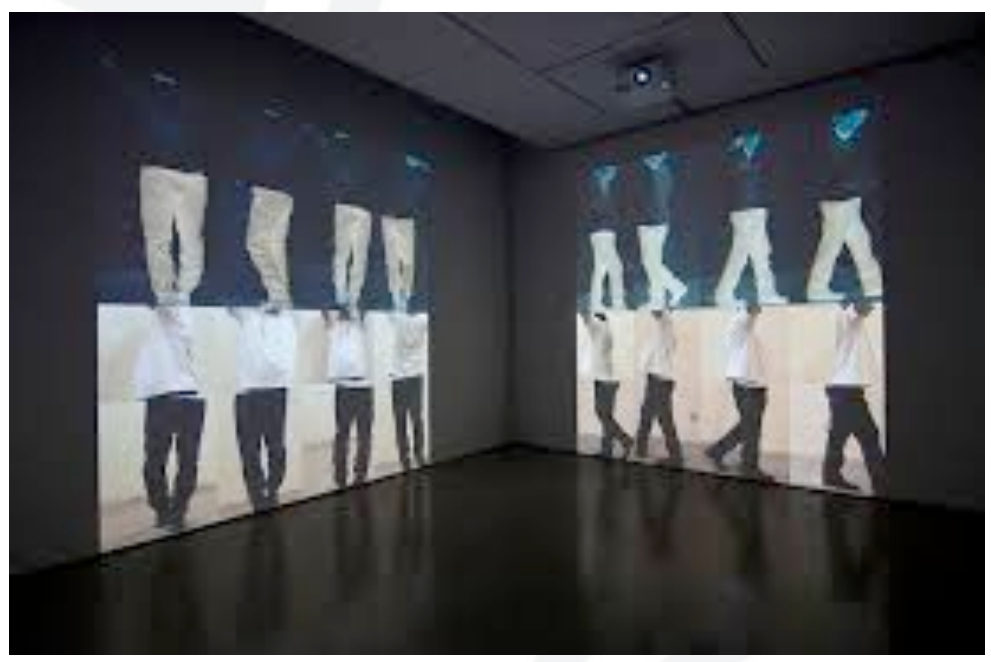

Figura 6: Contrapposto Studies iv e v, Bruce Nauman, 2015-16. Fonte: autoral

Os resultados disjuntivos desse processo de desaparecimento, Disappearing acts, título da retrospectiva do MOMA e PS1 remetem ao tema da imagemenigma, abordado no início desse artigo. Retomo aqui a questão proposta anteriormente: algo ocorrerá?

As projeções da Contrapposto trabalham simultaneamente o fenômeno do real e a metáfora do retorno do ausente - inexistente. Ocorre aí uma experiência de descontinuidade entre o presente e o que se anuncia. Os ambientes das instalações, com a amplificação e a privação das vivências multissensoriais desafiam as convenções e os simulacros conceituados por Baudrillard, dando lugar ao improvável e à percepção de cada um. Forçam o pensamento e a consciência corporal do visitante na busca pela verdadeira experiência estética. Os fenômenos utilizados - som, luz, movimento, acústica e tempo -, isolados, invertidos e retirados de contexto, criam uma relação entre o observador e uma obra de arte mais complexa, ambivalente e incongruente. É com o observador que a obra de arte acede ao seu verdadeiro 
ser - estético - e deixa de ser coisa entre coisas do mundo para se transformar em objeto estético.

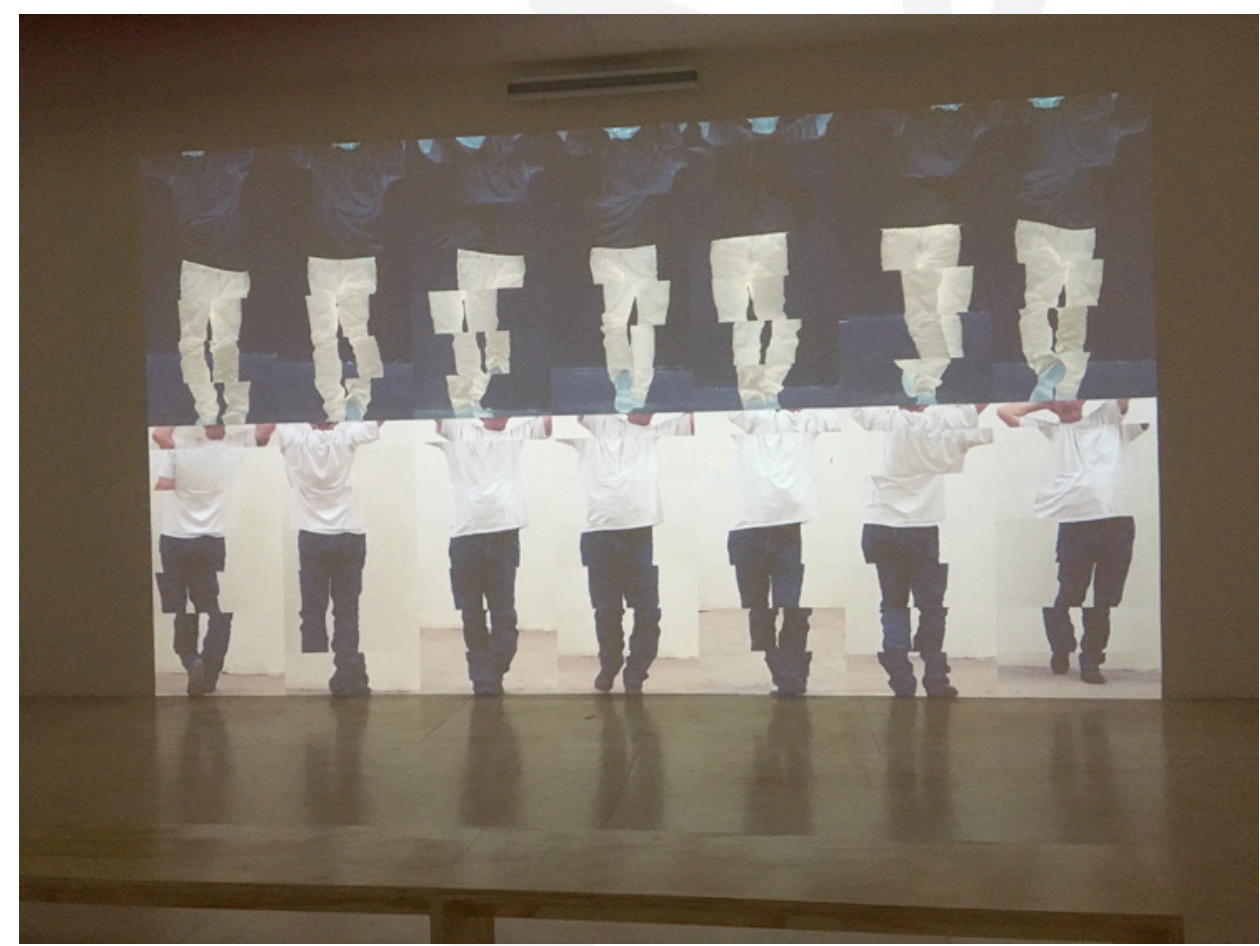

Figura 7: Contrapposto Studies vii, Bruce Nauman, 2015-16. Fonte: autoral

Nessa dinâmica, o corpo emerge como um meio de alternância entre o sujeito e o objeto, como ponto de mediação entre o observador e o entorno - o sujeito é o percebedor e o percebido, o sensor e o sentido-, numa relação dialética com o mundo que habita. É a partir da relação física com o espaço que ocorre o encontro emocional, sensorial e semântico do observador com o trabalho. Essas projeções criam imagens-enigmas e atuam contra a submissão massificante cultural de nossos dias. Produzem empatia nos visitantes, sequestrando-os do automatismo e ritmo frenético em que vivemos. Constróise, portanto, uma imagem que se opõe à imagem irreferencial, de desrealização do real (FRANKEL, 2018).

As projeções moldam as galerias com uma atmosfera que convida à experiência obtida a partir do engajamento tátil com a fisicalidade da luz que 
sensibiliza a experimentação do novo. Nesse ambiente imersivo, cabe ao visitante adequar a sua visão para se ajustar ao espaço, obrigando-o a se conscientizar do campo visual em seu entorno, propondo questões ao invés de fornecer respostas, e recrutando-o a uma apuração cognitiva, pois a luz e o espaço costumam ser fenômenos invisíveis e abstratos que não fazem parte da nossa realidade consciente. O observador é convidado a se perceber construindo a obra enquanto movimentava-se ao longo do espaço, sem chegar a lugar algum. Sob esse ponto de vista, faz-se necessário um aguçamento da sensibilidade para as matizes e nuances das imagens que mudam sutilmente de aspectos ou mesmo de sentido, dependendo da posição do observador. Trata-se, portanto, de uma tentativa para se evitar que o olhar fique refém da fascinação total, ou, dito de outra maneira, refém da profusão aleatória de signos da realidade virtual.

\section{CONCLUSÃO}

Essas instalações demonstram ser possível transformar gestos singulares em experiências complexas. $\mathrm{O}$ artista ao tecer imagens fragmentadas de seus movimentos em coreografias alternadas, mostra seu corpo como um meio, como instrumento para seus projetos. Nauman explora seu corpo dialeticamente, movendo-se entre privacidade e público, utiliza ferramentas reprodutivas da mídia massificadora - fotografia e vídeo-, para delas extrair uma atitude adversa. O uso do seu corpo como um sistema de movimentos, massa e equilíbrio rompe com estruturas convencionais e formais, num ato de invenção artística e dissolução da imagem vazia, do simulacro. O atraso e desincronizaçao dos movimentos Ihe permite desvendar e desvelar a imagem, transformando-a em imagem-enigma. Cada uma das instalaçoes forja uma certa solidão no visitante, desconectando-o da realidade espaço-temporal e arrastando-o para dentro dela; faz com que se experimente um espaço e tempo diversos do que ordinariamente se vivenciaria. Transforma a obra numa experiência sensorial que possibilita a construção perceptiva e multissensorial 
de cada um. Há um componente ritualístico nesse processo, uma espécie de coreografia que rebenta à medida em que o corpo se aproxima da obra.

Nesse sentido, as projeções são experimentadas em sua essência material e espacial de forma singular, como uma imagem mental que se funde às funções cognitivas. Considerando-se que vivemos em uma cultura de controle e velocidade, eficiência e racionalidade, na qual experiências e sensações são subestimadas quando comparadas a aspectos conceituais, intelectuais e de compreensão verbal, é imprescindível que haja projetos artísticos que ofereçam resistência, uma atitude crítica em relação à realidade da sociedade contemporânea.

\section{BIBLIOGRAFIA}

BAUDRILLARD, Jean. Simulacro e simulação. Lisboa: Relógio d'água, 1991.

BROWN, Julia. Occluded Front: James Turrell. Los Angeles: Lapis Press, 1985.

DEBORD, Guy. A Sociedade do Espetáculo. Lisboa: Mobilis in Mobile, 1997.

FABBRINI, Ricardo. A fruição dos novos museus. In: Especiarias, v.11 n. 19. São Paulo, 2008.

. Imagem e Enigma. In: Cadernos de Estética Aplicada, n. 19. São Paulo, 2016.

. Estética e Crítica da arte em Jean-François Lyotard. In: O que nos faz pensar, v.26 n. 40. São Paulo, 2017.

FRANKEL, David. Bruce Nauman, Disappearing Acts. Nova York: MOMA, 2018.

JAMESON, Fredric. Pós-modernismo: a lógica cultural do capitalismo tardio. São Paulo: Ática, 1998.

LIPOVETSKY, Gilles; SERROY, Jean. A Estetização do mundo - viver na era do Capitalismo Artista. São Paulo: Companhia das Letras, 2014.

WISNIK, Guilherme. Dentro do Nevoeiro: arquitetura, arte e tecnologias contemporâneas. São Paulo: Ubu, 2018. 


\section{LISTA DE FIGURAS}

Figura 1: Bridget's Bardot, James Turrell, 2008

Disponível em:

<https://azurebumble.files.wordpress.com/2010/07/bridgetsbardo_18a_2.jpg

>. Acesso em: Janeiro 2020. pág.: 17

Figura 2: Walk with Contrappostot, Bruce Nauman, 1968. Disponível em:

https://encrypted-

tbn0.gstatic.com/images?q=tbn\%3AANd9GcQeXRM6usb2wXQCRLUvwfx1g_kB

KtBp_ymArAw8qHtRZos2jG_H. Acesso em: Janeiro 2020. pág.: 20

Figura 3: Contrapposto Studies i e ii, Bruce Nauman, 2015-16.

Fonte: Autoral. pág.: 22

Figura 4: Contrapposto Studies iii, Bruce Nauman, 2015-16.

Fonte: Autoral. pág.: 23

Figura 5: Contrapposto Studies iv, Bruce Nauman, 2015-16.

Fonte: Autoral. pág.: 24

Figura 6: Contrapposto Studies iv e v, Bruce Nauman, 2015-16. Fonte: Autoral. pág.: 25

Figura 7: Contrapposto Studies vii, Bruce Nauman, 2015-16.

Fonte: Autoral. pág.: 26 